\title{
PRODUCTION OF FUNCTIONAL MILK DRINK BY USING SOME VITAL MATERIALS FROM WHEY
}

\author{
A.S.H.T. Bakr*; Moussa, M.A.M.**; Amer D. A. M* and Asmaa Khalil. M* \\ *Fac. Agric, Tanta Univ, Tanta, Egypt \\ ** Animal Pro. Res. Institute, Agric. Res. Center, Ministry of Agric, Egypt. \\ e.mail: Asmaa khalil864@gmail.com
}

\begin{abstract}
Cocoa drink fortified with biopeptides is made from whey (GMP), which has a high nutritional value. One of the most important results obtained was a simple and inexpensive method and the use of whey and sodium caseinate are cheap raw materials to isolate this compact (GMP).

The glycomacropeptide is rapidly absorbed, thus increasing the absorption of essential elements of the body such as iron, zinc and calcium.And the drink in which whey cheese is used as an aqueous solution contains a higher percentage of protein

Conclusively, It is possible to use glycomacropeptide obtained from whey as a substance that increases the nutritional value of healthy drinks or dairy products and the use of whey resulting from the manufacture of cheese, which is a by-product and is thrown into sewers and drains, despite the fact that it contains high-value nutritional compounds.
\end{abstract}

Key words: Glycomacropeptide .cheese whey. sialic acid.

\section{INTRODUCTION}

In the middle of the twentieth century, scientists first found evidence about the presence of protein bound sialic acid in milk (György et al., 1954) while working on a variant of Lactobacillus bifidus. They observed that human and cow milk contain some bifido-factor which is not destroyed or altered in its activity even by autoclaving, although the ash was found to be inactive. However, it was the pioneering work of French workers (Delfour et al., 1965) who for the first time established that milk contains a sialic acid bound protein called kappa-casein $(\kappa-\mathrm{CN})$. They also reported that glycomacropeptide (GMP), a sialic acid rich peptide, is formed by the cleavage of $\kappa-\mathrm{CN}$ between Phe105-Met106 by the action of rennet (chymosin) during the manufacture of cheese. It took many more years when GMP was taken as a new product opportunity. 
The GMP preparations until then were not pure enough to replace synthetic amino acid mixtures in the management of phenylketonuria and severe liver disease (Marshall, 1991). concentrations of GMP also exist in bovine milk. However, GMP released from casein is almost ten times higher than free GMP in mature milk (Furlanetti and Prata, 2003). GMP constitutes $20-25 \%$ of total proteins in whey products viz., whey powder, whey protein isolates (WPI), whey protein concentrates (WPC) etc., manufactured from cheese whey (Farías et al., 2010). It is recognized as a bioactive peptide and is thought to be an ingredient with a potential use in functional foods, and thus great interest has been generated for its isolation. The composition of GMP is variable and depends on the particular whey source and the fractionation technology employed in its isolation (Martín-Diana et al., 2006).

Earlier, attempts were mainly made to review the isolation and biological properties of GMP (Brody 2000; El-Salam et al., 1996; Thomä-Worringer et al., 2006).

Therefore, this article aims to discuss the chemical and functional properties of GMP and its role in the detection methods for checking cheese whey adulteration in milk and milk products. Some of the recent concepts used for the isolation of GMP from cheese whey are also discussed. According to Neemila et al. (2013).

\section{MATEERIALS AND METHODS}

Milk : Fresh buffalo Skim milk was obtained from the Sakha station. Rennet: It was obtained from chr, Hansen lab (Copenhagen Denmark).

Sodium caseinate : From the local market.

Sweet cheese whey: It is contain (T.S 7.08\%, T.P 1.37\%, Lactose 5.05\% and Ash 0.53\%).

Permeate: It is contain (T.S 5.35\%, T.p 0.18\%, Lactose 4.8\% and Ash 0.47\%). Sucrose: It was obtained the local market .

$\mathbf{N}$-acetylneuraminic acid: for the standard curve of sialic acid, was obtained from sigma, in powder form.

Cacao powder: It was obtained from the local market (T.S82.5\%, T.P 8.7\%, T. Carbohydrate70.4, lipids 3.4\%).

pH : Value was determined using a digital pH meter (Jenway $3505 \mathrm{pH}$ meter)

Total solids, Total protein and ash were determined according to AOAC (2007).

Sialic acid determination: Sialic acid was determined according to Lacomba et al.(2010) (Periodate- Resorcinol method). 
The reagents used for the quantitative assay: $0.04 \mathrm{M}$ periodic acid $\left(\mathrm{H}_{5} \mathrm{lO}_{6}\right)$. 0.6 gr of resorcinol (Fisher Certified Reagent) in solution containing $60 \mathrm{ml}$ of $28 \% \mathrm{HCl}, 40 \mathrm{ml}$ of water and $25 \mu$ moles of $\mathrm{CuSO}_{4}, 95 \%$ tert - butyl alcohol. The reagents were prepared fresh daily from stock $0.4 \mathrm{M}$ periodic acid and $6 \%$ resorcinol solution. The reagents were stable to storage at $-19^{0} \mathrm{C}$ in the dark expect the tert _ butyl alcohol which was maintained at room temperature.

\section{Sialic acid determination by HPLC:}

GMP was hydrolyzed with $0.1 \mathrm{~N}_{2} \mathrm{SO}_{4}$ at $80{ }^{0} \mathrm{C}$ for one hour for hydrolyzates of other carbohydrate, $2 \mathrm{~N} \mathrm{H}_{2} \mathrm{SO}_{4}$ at $100{ }^{0} \mathrm{C}$ was used, the hydrolyzates were filtered through $0.22 \mathrm{~mm}$ Millipore membrane filter (water Millipore, USA) and 20ml were injected into HPLC.

\section{HPLC of carbohydrates:}

HPLC waters Associates equipped with (sugar peak)

Column $(300 \times 605 \mathrm{~mm})$ at $90{ }^{\circ} \mathrm{C}$, Multisolvent Delivery system $600 \mathrm{E}$ and baseline 815 chromatography, work station, $20 \mu \mathrm{l}$ of samples were injected into HPLC. The detection was carried out using water 410 Refraction Index detector. the absorbed sugars were eluted isocratic all using the mobile phase calcium disodium EDTA and flow rate $0.5 \mathrm{ml} / \mathrm{min}$, and quantitative determination was carried and using the baseline 815 data system.

\section{Determination of amino acid profile of GMP:}

The amino acid contents of GMP were determined using HPLC-Pico- Tag method described in Millipore cooperative (1987).

A GMP sample corresponding to $40 \mathrm{mg}$ protein and hydrolyzed with 7.5 $\mathrm{ml}$ of $6 \mathrm{~N} \mathrm{HCL}$ at $110{ }^{\circ} \mathrm{C}$ for 24 hours.

The sample was made up to $25 \mathrm{ml}$ with HPLC grade water and filtered through $0.45 \mathrm{~mm}$ Millipore membrane.

Sample dehydration was coined out by placing $10 \mathrm{ml}$ in a vial and dries up in waters Pico-Tag workstation (waters, USA) for 10-15min at 250 military. Then $30 \mathrm{ml}$ of a drying solution (a mixture of $200 \mathrm{ml}$ methanol, $0.2 \mathrm{~N}$ sodium acetate acid $100 \mathrm{ml}$ triethylamine) was added to the sample and dried again in workstation.

The sample was then derivatized by adding $30 \mathrm{ml}$ of freshly prepared reagent $(50 \mathrm{ml}$ of phenyliso thiocyante (PITCO in 350 methanol ) and the reaction was carried out of $20 \mathrm{~min}$ and then dehydrated in the workstation for 15 min $.30 \mathrm{ml}$ of methanol was added and the tubes were redried again and 250 $\mathrm{ml}$ of sample diluents (water, USA)were added vortexed and transferred to injection vials $20 \mathrm{mlof}$ the sample were injected in Mail pore Reversed phase C4, amino acid column. 
Preparation of cheese whey to separate GMP:

Fresh buffalo skim milk was coagulated using rennet. The rennet casein curd was separated and the whey obtained was treated by combined acid and heat treatment to separate whey protein according to EL- Gazzar (1973). And there is no effect, heat and acid on GMP. Then the supernatant which was separated by centrifugation (6000 r.p.m-30 min) was concentrated by Rotary Evaporator.

\section{Preparation of GMP by using sodium caseinate as a raw material:}

For preparing rennet - casein curd sodium caseinate was dissolved in warm water at $50{ }^{\circ} \mathrm{C}$, the resultant solution(4\%) was cooled to $37{ }^{\circ} \mathrm{C}$ and maintained constant at that temperature then adjusting the $\mathrm{PH}$ to 6.4.

Rennet was added followed by hydrolyzing for $15 \mathrm{~min}$.then calcium chloride and lactic acid of $88 \%$ purity was added to precipitate calcium phosphate followed by mixing well. Then centrifuged to separate the precipitate.

The supernatant obtained was adjusted to $\mathrm{PH} 4.8$ and heated at $90^{\circ} \mathrm{C}$ for $10 \mathrm{~min}$.to in activate the enzyme, then cooled to $40^{\circ} \mathrm{C}$ and concentrated the liquid which contains GMP by Rotary Evaporator. The method described by Dosako et al. (1991).

\section{Preparation of cacao drink:}

Different ratio of concentrated GMP prepared from sweet cheese whey (5, $10,15 \% \mathrm{w} / \mathrm{v})$, cacao $(3,5,7 \% \mathrm{w} / \mathrm{v})$ and $2 \%$ sugar were mixed well dissolved either in sweet cheese whey or permeate and continued to $100 \mathrm{ml}$. Then heated at $80{ }^{\circ} \mathrm{C}$ for $15 \mathrm{~min}$ and cooled in water bath to $5{ }^{\circ} \mathrm{C}$ the product was stored at 4 ${ }^{0} \mathrm{C}$ in refrigerator.

\section{Sensory evaluation:}

Samples were sensory evaluated by regular taste panel 10 staff members of dairy Department in animal production research institute. Using scoring points, 50 points for flavor, 25 points for colour and 25 points for appearance. according to Shahani et al. (1979).

\section{Statistical analysis:}

Data achieved were statistically analyzed by the Genial Linear Model (GLM) procedure of SAS (2001).

\section{RESULTS AND DISCUSSION}

Simple and inexpensive methods for preparing glycomacropeptide (GMP):

Many researchers and health experts suggested that glycomacropeptide 
(GMP) appears to have many health benefits beyond nutrition and consider it a functional food researchers have indicated that GMP can be used as a medical foodstuff for individuals suffering from phenylketonuria (PKU). Patients with PKU cannot digest phenylalanine, an essential phenolic amino acid, due to a defect in the enzyme hydroxylase. GMP is interesting in that it is naturally low in phenylalanine and has the potential to be used as a protein source in PKU diets.

Generally the separation methods of GMP grouped in four groups, based on ion-exchange chromatography, gel filtration chromatography, ultra filtration and hydrophobic interaction chromatography.

However, these procedures are laboratory methods and not feasible for large scale manufacture, either because the materials are not food grade, the procedures are difficult to scale up and would generate much wastewater, or recovery is low (Nakano and Ozimek, 1999 and Nakano , 2000)

The worldwide availability of whey makes it the preferred starting material for preparing GMP As recovery of GMP from cheese whey is receiving much attention as an ingredient for special uses as a mean to modify the functional properties of whey protein concentrates (Veith and Reynolds, 2004). In this work two methods for preparing GMP from sweet cheese whey and also from sodium caseinat as a raw material were carried out.

\section{a: Using cheese whey to prepare concentrate glycomacropeptide:}

Cheese whey was a starting material to prepare GMP by combined acid and heat treatment to separate B -lactoglobulin and a-lactalbumin and they are removed by centrifugation. The supernatant obtained was considered as the GMP solution.lt was concentrated by vacuum evaporation.

Table (1) presented the composition of the GMP concentrate produced. Results showed that the total protein content ranged from 2.40 to 2.20 with an average value for- protein content in GMP concentrate of $2.30 \%$. This may indicate that GMP prepared contained proteins other than GMP. These results agreed with those obtained by Walstra and Jennies (1984) who reported that proteose and peptone are Known to remain into solution after the removal of acid heat denatured whey proteins.

Ash content of the concentrate GMP solution reached an average of 3.61\% (Max.3.80-Min.3.42).As for the carbohydrate content reached $34.11 \%$. This seemed high and that was due to the lactose content beside other sugars. 
Table (1): The composition of concentrate GMP prepared from cheese whey and from sodium casinate

\begin{tabular}{|l|l|l|l|l|l|l|}
\hline \multirow{2}{*}{ Composition } & \multicolumn{3}{|c|}{ GMP1 } & \multicolumn{3}{c|}{ GMPII } \\
\cline { 2 - 7 } & Max. & \multicolumn{1}{|c|}{ Min. } & \multicolumn{1}{|c|}{ Average } & Max. & \multicolumn{1}{c|}{ Min. } & \multicolumn{1}{c|}{ Average } \\
\hline pH & 5.4 & 4.8 & $5.1 \pm 0.06^{\mathrm{aA}}$ & 4.9 & 4.7 & $4.8 \pm 0.09^{\mathrm{bA}}$ \\
\hline T.S\% & 45.00 & 43.90 & $44.45 \pm 0.04^{\mathrm{aC}}$ & 23.09 & 21.91 & $22.50 \pm 0.01^{\mathrm{bA}}$ \\
\hline T.P\% & 2.4 & 2.2 & $2.3 \pm 0.03^{\mathrm{aB}}$ & 4.53 & 4.21 & $4.37 \pm 0.08^{\mathrm{bB}}$ \\
\hline T.carbohydrate\% & 38.01 & 36.21 & $37.11 \pm 0.05^{\mathrm{aA}}$ & 7.11 & 6.65 & $6.88 \pm 0.05^{\mathrm{bA}}$ \\
\hline Ash\% & 4.52 & 4.30 & $4.41 \pm 0.01^{\mathrm{aB}}$ & 8.41 & 8.33 & $8.37 \pm 0.06^{\mathrm{bA}}$ \\
\hline Sialic acid (gr/L) & 4.65 & 3.91 & $4.28 \pm 0.05^{\mathrm{aA}}$ & 4.09 & 4.11 & $4.1 \pm 0.03^{\mathrm{aB}}$ \\
\hline
\end{tabular}

Each analysis was carried out in duplicate

I: GMP prepared from cheese whey

II: GMP prepared from sodium casinate

\section{Sialic acid content of GMP}

Sialic acid is a key component of both human milk oligosaccharides and neural tissues may be a conditional nutrient during periods of rapid brain growth (Bing et al., 2007). GMP contains almost all the sialic acids (Nacetylneuraminic acid) in casein. Therefore, the determination of sialic acid can be taken as a measure of GMP (Warren, 1959). Also, Nakano and Ozimek (1999) reported that the determination of sialic acid is important to estimate the concentration of GMP. N-actylnuraminic acid (NANA). Its molecular weight is $309.28 \mathrm{gr} / \mathrm{M}\left(\mathrm{cnH}_{19} \mathrm{NO}_{9}\right)$

The quantitative determination of sialic acid in dairy products was modified by introducing a periodate oxidation step prior to heating with resorcinol reagent in comparing with the other methods used which need hydrolysis and the determination was spectrophotometricaly at $630 \mathrm{~nm}$. The periodate-resorcinol method was substantially more sensitive than the resorcinol procedure. It was not affected by lipids, amino acids or sugars, and was applied to detecttotal sialic acids (Locomba et al., 2010).

The concentration of sialic acid content in the sample was calculated according to the standard curve and the equation. $Y=2.34+455 \mathrm{X}$

$\mathrm{y}$ and $\mathrm{X}$ represented the concentration of sialic acid $(\mathrm{pg} / 0.5 \mathrm{ml})$ and the absorbance at $630 \mathrm{~nm}$, respectively.

\section{Recovery of sialic acid}

Recovery was carried out by adding known concentration of the standard solution of sialic acid (NANA) to the tested sample and calculated by the equation (AOAC, 2002)

$$
\mathrm{R} \%=(\mathrm{Cs}-\mathrm{Cp} / \mathrm{Ca}) .100
$$

Where $\mathrm{R}(\%)$ is the percent recovery of added standard, $\mathrm{C}_{\mathrm{s}}$ is sialic acid concentration in the sample, $\mathrm{C}_{\mathrm{p}}$ is sialic acid concentration in the original 
sample and $\mathrm{C}_{\mathrm{a}}$ is sialic acid concentration of the standard solution of sialic acid.

The recovery was carried out every assay run to correct the results obtained. It was found that the recovery of the sialic acid added to the sample ranged in between $86-91 \%$ with an average of $88.5 \%$.

Table (5) represented the average value of sialic acid content in the concentrate GMP prepared from cheese whey. It reached $4.28 \mathrm{gr} / \mathrm{L}$.

\section{B-using sodium caseinate as a raw material:}

In case of using sodium caseinate as a raw material for preparing rennet casein curd by enzymatic milk coagulating treatment with rennet. Then removing the resulting coagulum (rennet- casein) by centrifugation. The supernatant was hence free of whey proteins and lactose. The supernatant was concentrated by Rotarotry evaporator.

It was observed that the protein content of the concentrate GMP obtained reached an average of $4.37 \%$ (Table 1). This value seemed high; it was due to the decomposition casein fragments other than K- Casein. GMP which remained in the supernatant. That agreed with Dosako et al. (1991) who reported that the increase in protein content in GMP returned to the decomposition of casein fragment. The average value of sialic acid content in the concentrate GMP from sodium caseinate reached $4.10 \mathrm{~g} / \mathrm{L}$, and the ash content was $8.37 \%$.

The carbohydrate reached about 6.88\%. Lieste and Knorad (1996) mentioned that the ratio of glycosylated GMP to non-glycosylated raised and that increased the carbohydrate content in GMP. Also, Kawasaki et al. (1992) reported that most GMP was glycosylated.

\section{Amino acid contents of the concentrated GMP prepared from cheese whey and sodium caseinate.}

Table (2) Showed the amino acid contents of the prepared GMP. Results are agreed with Yun et al . (1996).

As GMP is rich in acidic amino acids (Glu), low in aromatic amino acids (Tyr, Phe and in Sulfur amino acids, Meth). Glutamic acid and Threonine were present in the highest amounts followed by Isoleucine and proline, followed by Aspartic, Valine and Serine. Also, the low content of phenylala nine was observed.

Producing cacao drinks fortified with glycomacropeptide using cheese whey or permeate as aqueous solutions.

Advances in dairy technology have made it possible to supplement infant formula or some functional foods with specific bovine milk proteins fractions, that to raise its biological activity or improve absorption of nutrients (Shannon 
BAKR et al.

Table(2):Amino acids content of the concentrate GMP prepared(mg/100ml)

\begin{tabular}{|c|c|c|}
\hline A.A & T I (mg/100ml) & T II (mg/100ml) \\
\hline Ala & 152 & 240 \\
\hline Arg & 72 & 97.9 \\
\hline Asp & 191 & 201.6 \\
\hline Glu & 304 & 414.1 \\
\hline Gly & 27 & 131 \\
\hline His* & 6 & 90.5 \\
\hline Isol * * & 208 & 213.7 \\
\hline Lea $* *$ & 60 & 180.2 \\
\hline Lys * & 150 & 210.7 \\
\hline Meth* & 48 & 150.7 \\
\hline Phe* & 12 & 28.8 \\
\hline Pro & 160 & 208.2 \\
\hline Thr* & 211 & 39.5.7 \\
\hline Tyr & 15 & 132 \\
\hline Ser & 103 & 150.1 \\
\hline Val $* *$ & 120 & 194.6 \\
\hline
\end{tabular}

T l=A.A GMP from cheese whey, TII =A.A GMP from sodium caseinate, A.A:Amino acids

$*=$ Essential amino acids , **=Branched chaine amino acid

et al., 2003). They found that the two proteins have such biological activity were glycomacropeptide, a carbohydrate rich casein peptide, which increases absorption of calcium, iron, or zinc, and a-lactalbumin, a major protein for promoting a plasma amino acids pattern, and increases calcium and zinc absorption.

\section{Using cheese whey and permeate as aqueous solutions:}

Cheese whey is an important potential-protein source. The whey protein although small in amount, is of the highest quality and most easily digested (El-Gazzar, 1973). It is particularly valuable because it supplies the body with all essential amino acids which present in whey protein in suitable proportion 
to support normal growth and production. Whey cheese is still a challenge to food technologists.

The relatively low total solids content only about $6 \%$ and low ratio between protein and lactose $0.14 / 70$ resulted higher drying cost. Cheese whey contains other values nutrients as minerals and vitamins. For the above mentioned importance of cheese whey and whey protein we are planning to find out the suitability for using cheese whey and permeate (is ultra filtered (UF) milk), permeate which composed of water, lactose, some minerals and non protein compounds as an aqueous solution to produce cacao drink fortified with GMP prepared (section I) and that would be a valuable nutritive and functional drinks for both enfant and adult .Different treatments were carried out beside the control which contained cheese whey or permeate plus sugar and cacao powder and without GMP. Among these treatments two treatments were acceptable and gained the highest score for panel, test while the others gained lesser scores which reached 60 out of 100 degrees.

\section{The two treatments were:}

a- cheese whey cacao drink fortified with $10 \%$ concentrate GMP (w/v) $+2 \%$ sucrose $(w / v)+3 \%$ cacao powder(w/v). This treatment gained 90 out of 100 degrees.

b-Permeate cacao drink fortified with $15 \%$ GMP (w/v) $+2 \%$ sucrose (w/v) $+4 \%$ cacao powder. This treatment gained 80 out of 100 degrees.

Results in Tables ( 3 and 4) presented the composition of the cheese whey cacao drink fortified with GMP at rate of $10 \% \mathrm{w} / \mathrm{v}$ and cacao powder $3 \% \mathrm{w} / \mathrm{v}$. The protein content in $100 \mathrm{~g}$ of the drink reached about $2.87 \%$, total carbohydrate $11.01 \%$. Total ash $0.81 \%$ and fat content was $0.10 \%$ while in case of using permeate instead of cheese whey the protein content was $1.60 \%$, total carbohydrate $12 \%$, ash 0.76 and fat reached $0.12 \%$. It was observed that the drink of cheese whey contained higher amount of protein than drink of permeate that retuned to cheese whey protein which increased the value of protein and also the ash content. Concerning the total calories in cheese whey cacao drink and permeate cacao drink were 56.42 and 55.48 calories per 100gr respectively.

\section{Sialic acid content:}

Sialic acid content for Tl and TII were $51.2 \mathrm{mg} / 100 \mathrm{~g}$ and $29.1 \mathrm{mg} / 100$ respectively. The determination was carried out by using HPLC. It was observed that value of sialic acid in treatment(l) is more than treatment (II). That may be due to using cheese whey in treatment(l) as an aqueous solution. 
Table (3): The chemical composition gr/100gr sample and calories per/100gr of the Cheese whey cacao drink.

\begin{tabular}{|l|c|}
\hline Composition & Value \\
\hline PH & 6.0 \\
\hline Total solids \% & 14.88 \\
\hline Total Protein \% & 2.87 \\
\hline Total carbohydrate \% & 11.01 \\
\hline Total ash \% & 0.89 \\
\hline Fat \% & 0.10 \\
\hline Sialic acid mg/100g & 51.2 \\
\hline Calories from protein & 11.48 \\
\hline Calories from carbohydrate & 44.04 \\
\hline calories from fat & 0.90 \\
\hline Total calories & 56.42 \\
\hline
\end{tabular}

Average of three replicates

Table (4): The chemical composition gr/100gr sample and calories per/100gr of the permeate cacao drink.

\begin{tabular}{|l|c|}
\hline Composition & Value \\
\hline PH & 6.0 \\
\hline Total solids \% & 13.49 \\
\hline Total protein \% & 1.60 \\
\hline Total carbohydrate \% & 12.00 \\
\hline Total ash & 0.76 \\
\hline Total fat \% & 0.12 \\
\hline Sialic acid mg /1 OOg & 29.1 \\
\hline Calories form protein & 6.40 \\
\hline Calories from carbohydrates & 48.00 \\
\hline Calories from fat & 1.08 \\
\hline Total calories & 55.46 \\
\hline
\end{tabular}

Average of three replicates

\section{Amino acid contents:}

Table (5) presented the amino acids content of cheese whey cacao drink fortified with glycomacropeptide $(10 \% \mathrm{w} / \mathrm{v})$ treatment I (Tl) and permeate cacao drink fortified with $(15 \% \mathrm{w} / \mathrm{v})$ glycomacropeptide treatment II ( T II).Data obtained showed that the highest value was for Alanine follow by Threonine, Glutamic acid, Arginine, valine, Lysine, Leucine and Isoleucine 
Table (5): Amino acid contents (A.A) of cheese whey cacao drink (I) and permeate cacao drink (1l).mg/100ml

\begin{tabular}{|l|c|c|}
\hline \multicolumn{1}{|c|}{ A.A } & I & II \\
\hline Ala & 270 & 130 \\
\hline Arg & 205 & 62 \\
\hline Asp & 128 & 87 \\
\hline Glu & 210 & 100 \\
\hline Gly & 110 & 88 \\
\hline His* & 140 & 62 \\
\hline Isleu** & 150 & 50 \\
\hline Leu** & 175 & 68 \\
\hline Lys* & 190 & 82 \\
\hline Meth* & 101 & 60 \\
\hline Phe* & 103 & 70 \\
\hline Pro & 105 & 26 \\
\hline Thr* & 220 & 86 \\
\hline Tyr & 122 & 78 \\
\hline Ser & 90 & 60 \\
\hline Val * & 201 & 98 \\
\hline A.A A & 904 & \\
\hline
\end{tabular}

A.A=Amino acid , l=A.A GMP from cheese whey, II=A.A GMP from sodium caseinate

$*=$ Essential amino acids

$* *=$ Branched chain amino acids

and the lowest value obtained was for serine (Tl). However in treatment II in which permeate was used as an aqueous solution, data obtained showed that the highest value was for Alanine, followed by Glutamic acid and the lowest was for Iso-leucine

Conclusively, it is possible to use glycomacropeptide obtained from whey as a substance that increases the nutritional value of healthy drinks or dairy products and the use of whey resulting from the manufacture of cheese, which is a by- product and is thrown into sewers and drains, despite the fact that it contains high-value nutritional compounds.

\section{REFERENCES}

A.O.A.C (2007) Official Methods of Analysis (18 ${ }^{\text {th }}$ Ed.) Helrich, K. and W. Hornitz (eds). Pub Association of Official analytical chemists Washington. D.C.U. S.A. 
Bing, W.; Bing Y.; Muhsin K.; Honghua H.; Yun S.; McGreevy, P.; Petocz, P.; Held, S. and Brand-Miller; - (2007) Dietary sialic_acid supplementation improves learning and memory in piglets. Am. $J$. Clin. Nutr.; 85:561-569.

Dosako S, Nishiya T and Deya E (1991) Process for the production of Kappacasein glycomacropeptide. United States Patent, 5041622.

EL.Gazzar. H. (1973). Utilization of dairy by products in the manufuctor of same type of soft cheese $\mathrm{Ph}$. D.Thesis, Faculty of Agriculture. Ain Shams University, Egypt.

Kawasaki Y, Isoda H. Tanimoto M, Dosako S, Idota $T$ and Ahiko K (1992) Inhibition by lactoferrin and k-casein glycomacropeptide of binding of cholera toxin to its receptor. Bioscience, Biotechnology and Biochemistry, 56: 195-198.

Lacomba, R, Jaim, S. Amparo, A., Jesus, L., Reyers, B, and Metenio. (2010). J Pharmaceutical and Bioemdical analysis. 51-346-357.

Lieste and Knorad G. 1996. A new method to estimate caseinomacropeptide and glycomacropeptide from tricholoracetic acid filtrates. Milch wissen aschaft, 51 (8): 431-435.

Millipore Cooperative (1987). "Liquid chromatographic analysis of amino acids in foods using a modification of the Pico - tag method".

Nakano $T$ and Ozimek L. 1999. Purification of glycomacropeptide from non-dialyzable fraction of sweet whey by anion-exchange chromatography. Biotechnol Tech., 13(11):739-742.

Nakano T.(2000) Sialic acid in human milk: Compositions and functions. Acta Paediatr 42: 11-17

Neelima . Rajan Sharma. Yudhishthir Singh Rajput .Bimlesh Mann (2013)chemical and functional properties of glycomacropeptide (GMP)and its role in the detection of cheese whey adultration in milk.

SAS (2001). SAS/STAT User's Guide, Version 8. Cary, NC: SAS Institute Inc.

Shahani, K, M, and R, C, Chandan (1979). Nutritional and healthful aspects of cultured and Culture containing dairy foods. J. Dairy Sci., 62(2): 1685-1694. doi: 10.3168/jds.S0022-0302(79)83481-5

Shannon L Kelleher; Dereck Chatterton; Karin Nielsen and Bo Lonnerdal (2003) Glycomacropeptide and a lactalbumin supplementation of infant formula affects growth and nutritional status in infant rhesus monkeys. Am J. Clin. Nutr., 77:1261-8.

Veith,P.and Reynold, E. C. (2004). Production of a high gel strength whey protein concentrate from cheese whey. J. Dairy Sci.,87: 831-840. 
Walstra P. and Jenness R. (1984). Dairy Chemistry And Physics. John Wily and Sons, New York, Ny

Warren, L. (1959). The thiobarbituric acid assay of sialic acids. $J$. Biol. Chem., 177: 751-766

Yun S. S.; Sugita-Konishi. Y,; Kumagai S. and Yamauchi K (1996) Glycomacropeptide from cheese whey protein concentrate enhances $\lg$ A production by lipopolysaccharide-stimulated spleen cells. Animal Science and Technology (Japan), 67: 458-462.

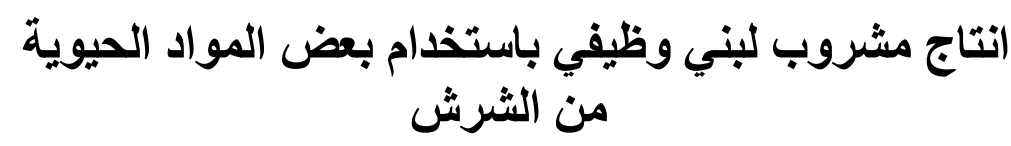

$$
\begin{aligned}
& \text { أشرف شعبان طه بكر } 1 \text { ـ محمد عرفه محمد موسى } 2 \text {-ـ دينا احمد مرتضى عامر } 1 \text { - } \\
& \text { أسماء خليل محمد فئان }
\end{aligned}
$$

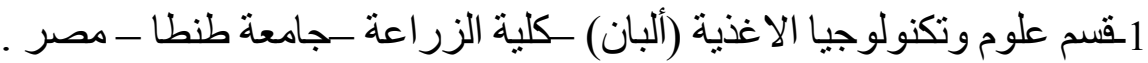

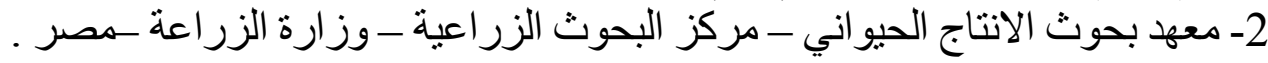

$$
\begin{aligned}
& \text { تم تصنيع مشروب كاكاو مدعم بالبييتيدات الحيوية من الثرش } \\
& \text { (الجليكو ماكروبييتيد) و التي لها قيمة غذائيه عالية. }
\end{aligned}
$$

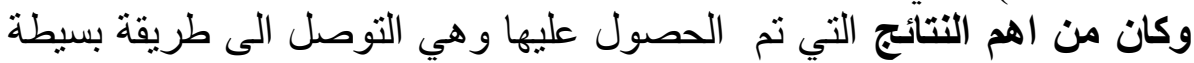

$$
\begin{aligned}
& \text { وغير مكلفة واستخدام فيها مواد تعزل هذا المركب من الثرش او ماده كازينات } \\
& \text { الصوديوم كمو اد خام رخيصه. }
\end{aligned}
$$

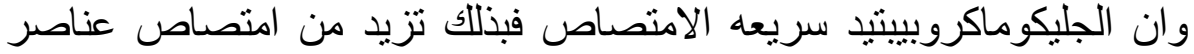

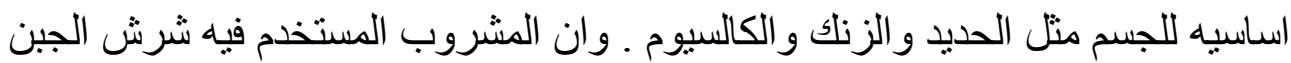

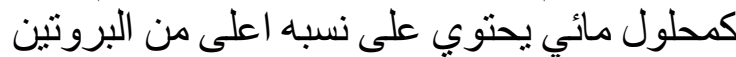

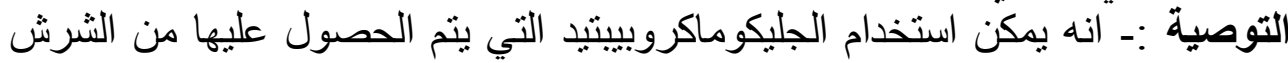

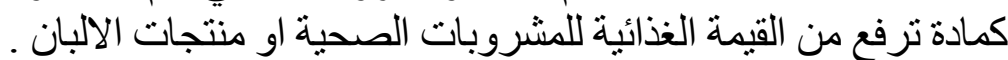

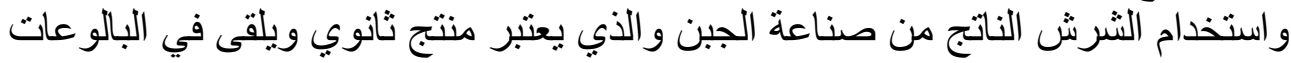

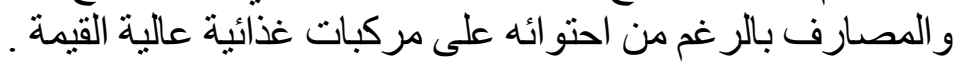


BAKR et al. 